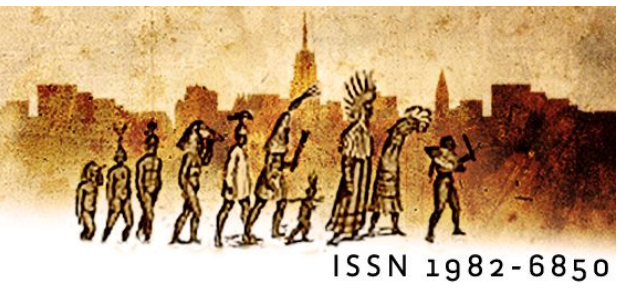

\title{
Review of L'amica geniale: infanzia, adolescenza (Rome: Edizioni e/o, 2011), by Elena Ferrante
}

\author{
Martha LaFollette Miller ${ }^{i}$ (University of North Carolina at Charlotte)
}

James Wood, in a 2013 article in the New Yorker, called Elena Ferrante "one of Italy's best-known least-known contemporary writers." Meghan O'Rourke, in 2014 in The Guardian, similarly referred to her as "the global literary sensation nobody knows." These comments refer to both the excitement that her works have generated among her reading public and to the reclusiveness she cultivates by hiding her identity behind a pseudonym and assiduously avoiding the public eye. It was Wood's description of Ferrante's "remarkable, lucid, austerely honest novels" that led me to read L'amica geniale (2011) and to seek out as well her earlier works. ${ }^{1}$ Soon I too was hooked. I eagerly awaited and then devoured each of her three subsequent novels, published in astonishingly rapid succession under the titles Storia del nuovo cognome (2012), Storia di chi fugge e di chi resta (2013), and Storia della bambina perduta (2014). The four books published between 2011 and 2015 constitute for Ferrante a single work - a unified tetralogy she refers to globally as $L^{\prime}$ 'amica geniale. ${ }^{2} \mathrm{~A}$ Portuguese translation of the first volume of the tetralogy was released on May 29, 2015 in Brazil (Globo Livros, trans. Maurício

\footnotetext{
${ }^{1}$ Novels include L'amore molesto (1992), I giorni dell'abbandono (2002); and La figlia oscura (2006). La frantumaglia (2003) ["the act of falling apart"] is a volume of her correspondence with editors and others, intended to shed light on who she is without revealing her identity. Translations of the novels, all by Ann Goldstein, were published in New York, with the following titles and dates: Troubling Love (2006), The Days of Abandonment (2005), and The Lost Daughter (2008).

2 These works have been translated into English by Ann Goldstein under the following titles My Brilliant Friend (2012); The Story of a New Name (2013); Those Who Leave and Those Who Stay (2014); and The Story of the Lost Child (to be published in September, 2015).
} 
Santana Dias). ${ }^{3}$ Translations of the other three volumes are sure to come out in short order, bringing the entire tetralogy to an even larger audience than before. In this first (and arguably most appealing) volume in the series, the foundation is laid for the tale of the extraordinary, decades-long relationship between two exceptionally bright girls born into poor working class families in post-Second World War Naples. The perceptive narrator, Elena, and Lila, her "brilliant friend," are marked by the life of their violent, corrupt and misogynist neighborhood but are also shaped by the friendship they develop. The bond between the two is forged early in life and is intense and inexplicable. (Elena traces its beginning to the moment they clasped hands as they ascended a staircase to jointly confront the neighborhood ogre, Don Achille, for allegedly stealing their dolls.)

As the opening pages of L'amica geniale make clear, Elena, now in her sixties, has decided to write the chronicle of the long-enduring friendship after Lila, always unpredictable, disappears without a trace. The tetralogy is thus at first glance a memoir. But instead of retrospective analysis or of remembrances viewed through the lenses of what has transpired over the years, the author chronicles them as they happen and as Elena experiences them. Elena's narration re-creates with thick particularity and total immediacy the details not only of the friendship and of her ongoing emotional life but also the social, commercial, and political intricacies of the rough and seamy neighborhood as a whole. More than friends, Elena and Lila are in a symbiotic relationship of imitation and competition, of entanglement and control, exemplifying the permeable borders which are sometimes said to be characteristic of women.

In childhood, Elena - an introspective and at the same time keenly observant narrator - reveals her fascination with the brilliant, charismatic, yet sometimes cruel Lila. Elena loves Lila for the synergy between them, which inspires her and stimulates her to achieve. Through persistence and effort, Elena manages to claw her way out of the educationally and economically deprived childhood setting she is born into to eventually earn a doctorate and to become an acclaimed writer. (Like Ferrante herself, she becomes famous for her portrayal of working-class Naples). Through all of this, she deals with the shadow of Lila, the brilliant friend

\footnotetext{
${ }^{3}$ A translation by Margarida Periquito had appeared in Portugal in November, 2014.
} 
whom she adores and whose vitality she needs but who alternates disconcertingly between supportiveness, indifference, and one-upmanship. Lila, who compared to Elena seems to have the more natural creative genius and the more effortless academic ability, is sadly prevented by her parents from going beyond elementary school. She responds by forging her own brilliant but tortuous path, first by designing fine shoes and marketing them and then by pioneering the use and management of computers in their area. Though she maintains a façade of selfsufficiency, Lila's admiration of Elena's academic success and her vulnerability to her friend sometimes become apparent, as when she secretly cultivates the life of the mind by reading and doing research but hides this activity from Elena. (Their divergent life trajectories could also be read as embodying in symbolic form the competing sides and multiple possibilities of a single self.) Throughout, the contrast between Elena's sustained exposure of her own ongoing emotional life on the one hand and her description of Lila's stubborn otherness on the other creates a persistent tension in the account of the decades-long relationship. Lila, whose actions surprise us to the end, remains a mystery and an enigma.

A significant question in connection with Ferrante's literary career revolves around the issue of the response to her works in Italy in comparison to their international reception. Despite the excitement Ferrante's works have generated in Italy and internationally, her novels have not been universally acclaimed in her homeland. Paolo Di Paolo's condescending article in La Stampa dismisses her popularity in the US as a result of American superficiality regarding Italian culture. He describes the acclaim toward Ferrante as "sproporzionato" [out of proportion] and questions the universality some see in her works. He is particularly hostile to her anonymity, which to him is "infinitamente meno interessante di una vita, di una faccia [infinitely less interesting than a life, a face]. Without a face, says Di Paolo, literature runs the risk of resembling stories produced by a computer program. Di Paolo is not the only one who has failed to embrace her as what she claims to be. Some have speculated that she hides because she is really a man (perhaps author Domenico Starnone) or even a team of writers. Both hypotheses seem highly improbable given the depth of her portrayal of female experience, the complexity of her characters, and the consistency and quality of her style. Yet even a laudatory editorial in Corriere della sera, by Pierluigi Battista, does not totally accept her assertion that 
she is a woman, referring to her as "una scrittrice (?)" [a woman writer (?)]. Not only Ferrante's anonymity but also critical reactions such as Di Paolo's raise questions about the climate in Italy for women in general and for women writers in particular. Her choice of anonymity may be annoying to some but makes sense when we consider her express desire, as a writer who draws on her own life and that of others she has known, to protect privacy (La frantumaglia, 63). In addition, she may prefer that her writings speak for themselves because of the personal scrutiny that women writers have historically been subjected to on a personal level. In a patriarchal world where women are expected to know their place and in some senses are male possessions, her boundary-setting may cause resentment.

Di Paolo's attempt to discredit Ferrante echoes the dismissiveness that has plagued women writers for centuries and which Joanna Russ insightfully described in the feminist classic How to Suppress Women's Writing (U Texas P,1983). A critical ploy that Russ terms "denial of agency" (the claim that "She didn't write it; he did" [21]) has clearly been applied to Ferrante. Costanza Rizzacasa d'Orsogna has described Italian letters as plagued by a "ferocious sexism" that leads to the assumption that because the works are so good, "Elena Ferrante" must be the pseudonym of a man (quoted by Heyman). Another maneuver Russ identifies is the "pollution of agency" through which what a woman writes is judged by different standards than what men write. Russ describes how the reception of Wuthering Heights changed when it came to be known to have been authored by a woman: the focus shifted from the work itself to the life of the woman author (42-43). In Ferrante's case, anonymity thwarts this demeaning practice. Interestingly, Ferrante embeds into her fiction another ploy used to discredit women writers: what Russ calls "the double standard of content." When her narrator, like herself named Elena, returns to Naples after publishing a successful autobiographical novel based on some of her traumatic experiences growing up in the neighborhood, she is chastised for casting a negative light on its inhabitants and shamed as well for the sexual content of her writing.

On June 10, 2015, Storia della bambina perduta, part 4 of Ferrante's tetralogy, was named - amidst some controversy over whether writers who fail to identify themselves should be eligible - as one of five finalists for the prestigious 70-year old Strega Prize, due to be awarded on July 2, 2015. Her nomination raised the question of whether Italy would fully 
embrace Ferrante and her growing international acclaim. From the outset she was clearly fighting an uphill battle for the prize in this competition that over the years has been particularly hard on women writers: of the 68 previous Strega winners, only nine had been women, and the preceding twelve prizes had all been awarded to men. Because the award is exclusively earmarked for a novel published in 2015 , the first three installments of Ferrante's tetralogy could not be taken into consideration, a fact that further clouded Ferrante's prospects. But based on my own unbridled enthusiasm for her work, I was cautiously optimistic that the writer who Rachel Donadio calls "Italy's great, mysterious storyteller" would not be denied her due. As it turned out, however, Ferrante came in third in the competition, and the award again went to one of the male contenders.

\section{Works Cited}

BATTISTA, Pierluigi. "Elogio dello Strega a Elena Ferrante." Corriere della Sera 23 Feb. 2015. Web. 28 Aug. 2015.

DI PAOLO, Paolo. "Il caso Ferrante, il romanzo italiano secondo il New Yorker" [The Ferrante case, the Italian novel according to The New Yorker] 13 Oct. 2013. Web. 28 Aug. 2015.

DONADIO, Rachel. The New York Review of Books 18 Dec. 2014. Web. 28 Aug. 2015.

FERRANTE, Elena. A amiga genial. Portuguese translation by Margarida Periquito of L'amica geniale. Lisbon: Relógio D'Água Editores, 2014.

. A amiga genial. Portuguese translation by Maurício Santana Dias. São Paulo: Globo Livros, 2015.

. The Days of Abandonment. English translation by Ann Goldstein of I giorni dell'abbandono. New York: Europa Editions, 2005.

. I giorni dell'abbandono. Rome: E/O, 2002.

L'amica geniale. Rome: E/O, 2011.

. La figlia oscura. Rome: E/O, 2006.

. La frantumaglia [the act of falling apart]. Rome: E/O, 2003. 
. L'amore molesto. Rome: E/O, 1992.

. The Lost Daughter. English translation by Ann Goldstein of Storia della bambina perduta. New York: Europa Editions, 2008.

Storia della bambina perduta. Rome: E/O, 2014.

Storia del nuovo cognome. Rome: E/O, 2012.

Storia di chi fugge e di chi resta. Rome: E/O, 2013.

. Troubling Love. English translation by Ann Goldstein of L'amore molesto. New York: Europa Editions, 2006.

HEYMAN, Stephen. "The Makings of a Prize-Winning Book." The New York Times 26 Nov. 2014. Web. 28 Aug. 2015.

O'ROURKE, Meghan. "Elena Ferrante: The Global Literary Sensation Nobody Knows." The Guardian 31 Oct. 2014. Web. 28 Aug. 2015.

RUSS, Joanna. How to Suppress Women's Writing. Austin: University of Texas Press, 1983.

WOOD, James. "Women on the Verge: The Fiction of Elena Ferrante." The New Yorker 21 Jan. 2013. Web. 28 Aug. 2015.

i Martha LaFollette MILLER, Professor Emerita of Spanish University of North Carolina at Charlotte mlmiller@uncc.edu 